Informatika i sistemy upravleniya. - 2018. - No. 1(55). - P. 3-15.

Grigorev Yu.A. (grigorev@bmstu.ru)

Bauman Moscow State Technical University

\title{
ABOUT THE USE OF COST MODEL FOR PREDICTION OF DATABASE QUERY EXECUTION
} TIME

The article analyses the possibility of applying the cost model of the database query optimizer for evaluating the execution time of the Select statements. It is proved that when using a calibrated cost model, the relative error in calculating the query execution time tends to zero. In this context the database volume increases, even if the cardinality is inaccurate.

Keywords: cost model, query optimizer, time prediction, estimation error.

DOI: 10.22250/isu.2018.55.3-15

For citation:

Grigorev Yu.A. ABOUT THE USE OF COST MODEL FOR PREDICTION OF DATABASE QUERY EXECUTION TIME // Informatika i sistemy upravleniya. - 2018. - No. 1(55). - P. 3-15. 